FROM THE PRESIDENT OF RUSA

Anne M. Houston, President

\section{Building Your Professional Toolkit}

Anne M. Houston, RUSA President 2015-16

Anne M. Houston is Director of Teaching, Learning, and Research, Smith College Libraries, Northhampton, Massachusetts; email:annehouston2@gmail.com.
A s RUSA president I'm often asked for career advice. How can I get my first professional job? How can I succeed in it and build my career? How do I make the next move to a higher level position? The job market for librarians isn't as extensive and robust as we'd like it to be, but at the same time, good jobs are out there-jobs that have the potential for growth and offer possibilities for meaningful work. As someone who has been the hiring manager for many librarian positions throughout my career, including many entry-level positions, I can tell you that there is competition for the best jobs and that our needs as employers are becoming more complex. How can you position yourself to compete in this job market? How can you build a successful, rewarding career?

The first and most important piece of advice that I'd give to new professionals is to recognize that very few librarian positions are truly entry-level any more. Most require some experience, often in an emerging subfield of librarianship. If you take a look at the ALA Joblist you'll notice that professional positions, even those that do not involve supervision or management, generally ask for experience in a specific area. MLS candidates should be aware of this and plan accordingly. If your program offers internships or the opportunity to work in the institution's libraries, take full advantage of these opportunities and seek out significant work experiences to begin building your résumé while you are still an MLS student. If you're working in a library in a paraprofessional position, ask for opportunities to engage in professional work. My library has had several staff members working on their MLS degrees who have been able to assist in teaching or work on innovative projects that are outside the scope of their job descriptions. It's a win-win situation, helping the library to move forward on key initiatives while allowing the employees to gain valuable experience. An added benefit for the MLS student who pursues significant work experience is getting to know librarians who can serve as references. If you're not sure what sort of experience to pursue, look at the ALA job listings, identify positions of interest to you, examine the required qualifications and position yourself to be a strong candidate by working toward the qualifications listed. Remember that libraries are desperately seeking professionals who show evidence of innovation and creativity. You may want to put together a portfolio that documents your ability to be creative through photos, blog posts, or other concrete evidence.

New professionals also should recognize the importance of nurturing their own leadership potential. The best route to future success in the profession is to build your leadership 
toolkit regardless of what level of job you are seeking. Leaders are in demand at all levels, whether or not the specific role calls for management or supervision. The potential for leadership is the one quality I have considered most important even for those coming directly out of library school. I look for tangible evidence of this on résumés and want to see leadership strengths called out in a candidate's cover letter. I look for qualities such as the ability to organize groups and teams, to motivate other people, and to set and achieve goals. I need leaders on my team because, given the demanding nature of library work today, I don't have time to lead all projects myself. I have to be able to delegate an important initiative to a librarian who I trust to be an effective leader. For example, I was recently able to assign an important meeting with our college development office-on a day when I was out of town at the ALA Midwinter Meeting-to a relatively new librarian on my team, who I trust to speak effectively and accurately about the library's priorities.

Libraries also seek professionals who are thoughtful about the future of libraries. What is your vision for the future? You don't need a crystal ball to formulate an answer to this question. You can start by connecting with the research done by smart people and organizations in the library field. For example, you might want to read the annual Horizon Reports put out by the New Media Consortium, which forecast technology trends in education and libraries. Academic librarians may want to follow the good work done by the EDUCAUSE Learning Initiative, such as their 7 Things You Should Know About ... series. All librarians should read or browse American Libraries and Library Journal. Follow the Twitter feeds of forward-thinking groups that interest you. I follow the Pew Research Center, for example, to hear immediately about their new research on library use. Job candidates are often asked how they keep current on developments in the profession. Be prepared to answer this question and then to show that you have thought about the key issues in libraries today and what they mean for the future. Remember that you don't need to have the right answer all the time. None of us do! The important thing is that you have some ideas about where libraries might be going.

Another factor that is vital for new librarians, both in job hunting and in their future success, is an understanding of the organizational culture of the profession, which is transforming but retains certain values that are consistent over time. Librarianship can accurately be called a profession, if we define profession as Webster's does: "a type of job that requires special education, training, or skill."' Professions are characterized by the need for a particular body of knowledge that is unique to that profession, and with it the theoretical grounding that underlies that body of knowledge. The body of knowledge underlying library work is the understanding of how information is created, structured, organized, and disseminated, and the educational principles needed to translate those systems of organization to information seekers. But librarianship could also be called a vocation, defined by Webster's as "a strong desire to spend your life doing a certain kind of work (such as religious work)."' This sense of vocation is something that I've found most librarians to have. Librarians are driven by a passion for learning, a belief in intellectual freedom, a commitment to service, and a dedication to the public good. For example, this sense of purpose drives our desire for the new Librarian of Congress to be a professional librarian (an issue not yet resolved as I write this). We want our top leaders to feel as strongly as we do about the importance of libraries to society and the need to strengthen libraries' unique role in their communities and in society as a whole. The point I am making is that for librarians, their work is not "just a job," and I would ask anyone who is considering pursuing the profession whether they feel a sense of commitment.

Commitment is a key motivating factor for librarians as they move forward in what is becoming an increasingly challenging profession. Librarian jobs have become more specialized, involving emerging areas such as user experience, digital scholarship, instructional technology, and data management. It is not uncommon now for a typical job to involve general reference librarianship or liaison work combined with a specific area of expertise such as one of the above. Sometimes a job will morph into something new as an area of need emerges in a library. In this environment the ability to engage in self-directed learning is important, especially given that libraries often lack the travel and training budgets to fund extensive continuing education for their staff. Luckily, many low-cost or even free professional development options are available for librarians who seek them out. Finding time for learning in our daily work can be difficult or even impossible, but it is necessary if we are to remain relevant as a profession.

Learning is just one of the priorities that we need to balance in our jobs. As I described in my previous column in this space, the roles of reference librarians involve an increasing number of diverse competencies including the ability to counsel, to teach, and to advocate. To be successful we need to find time and head space for all of these things. It is worth taking time each day to ask, "What is most important for me to focus on today? What are both my short term and long-term priorities?" Balancing the immediate need to serve the patron in front of us with the need to train ourselves to serve the needs of future patrons is one of our most challenging tasks. All of this sounds complicated, and it is. I believe that our profession is becoming increasingly difficult and at the same time more rewarding. As ALA's current Libraries Transform campaign reminds us, we are facing a period of remarkable transformation in which libraries constantly encounter opportunities to serve people in new ways. This makes it a great time to become a librarian for those who are willing to be challenged and work toward creative solutions to important problems.

Finally, some advice about the job search process. Find a mentor who is willing to be honest with you about your résumé and qualifications. RUSA offers a speed mentoring program at the Midwinter Meeting that you may want to 


\section{FROM THE PRESIDENT OF RUSA}

check out, and some institutions offer formal mentoring programs. Often mentoring happens organically because you find someone you feel comfortable approaching for advice. Your mentor doesn't need to be a senior leader; he or she can be friend who has been successful in the profession and whose opinion you respect. Ask that person to read over your application materials and help you prep for interviews.

As you look at job postings, keep in mind that it doesn't hurt to cast a wide net in terms of applying for positions of interest to you-but take the time in your cover letter to address your specific qualifications for the particular position you're applying for. Once you've earned an interview, commit yourself to the search process by engaging fully with the position. This means spending time with the position description and the library's website to tailor your responses and your questions to the situation at hand. If you are asked to give a presentation on a particular topic, make sure you address the topic — don't use a generic presentation or something you've prepared for another purpose. A search committee is looking to find out why you want this particular job, and so you should prepare to show that you can address the specific qualities that are being sought. Write down all the questions you can think of that the search committee might ask you, and think of how you will answer them. You can predict that you will likely be asked a question about each qualification listed in the job description. Many interview questions are essentially the same questions asked in different ways, so having answers prepared for common questions will help you be ready for other questions that come up. For example, thinking through how you would describe, in detail, several of your most important accomplishments will help you be ready for any of these often-asked questions: Tell us about a time when you found a creative solution to a problem. Give us an example of your ability to be innovative. Tell us about a project that you are particularly proud of. Take some notes for yourself that you can refer to throughout the interview.

The following may sound obvious, but I've interviewed so many candidates, and seen so many avoidable mistakes, that I feel obliged to write about them in hopes that I might reach at least one MLS graduate and prevent them from going down the wrong path. Recognize how small the profession can be, that everyone knows everyone else, and think twice about doing anything that might be interpreted as bad behavior-don't use profanity, complain about your current institution, or criticize the institution interviewing you. Sadly, I have witnessed each of the above on more than one occasion. Don't ask questions that can easily be answered on the library's website- that just says that you don't know how to research. If you lose interest in the position in the middle of the interview, don't make that obvious to the interviewer. You may change your mind or want to apply again at the same institution. If you're taken out for a meal, remember that while the environment is more casual than the rest of the interview, you are still on stage. These "don'ts" are really just common sense and are entirely avoidable.

A career counselor once gave me some useful words of wisdom about interviews. When your application is being considered against 100-plus others that have been submitted, employers are so overwhelmed that their goal is to narrow down the field as quickly and efficiently as possible. So make your suitability for the position obvious at the beginning of your cover letter and at the top of your résumé. But also keep in mind that once an institution brings you in for an onsite interview, they have committed time and money to you and are looking for reasons to accept you-rather than to reject you. To calm your nerves for an on-site interview, just remember that the good will is on your side at that point. The institution wants to choose someone they have brought in, not go back to the drawing board. Use that good will to your advantage.

What advice do you have about library careers and the job search process? What questions do you have? I'd be happy to hear from you and to share comments and questions at the next RUSA speed mentoring program. Feel free to contact me at annehouston2@gmail.com.

\section{References}

1. Merriam-Webster Online, s.v. "profession," accessed March 29, 2016, www.merriam-webster.com/dictionary/profession.

2. Merriam-Webster Online, s.v. "vocation," accessed March 29, 2016, www.merriam-webster.com/dictionary/vocation. 